\title{
Influence of physical activity on a treadmill on the metabolism of adipose tissue in rats
}

\author{
By JANA PAR̆fZKOVA AND LIBUŠE STAŇKOVA \\ Physical Culture Research Institute, Prague \\ (Received I6 December 1963-Accepted 9 March 1964)
}

Intense exercise is an important physiological stimulus and adaptative processes produced by it cause a number of functional and morphological changes in the organism. One of them is, for instance, the attainment of a typical body composition, with a greater proportion of lean body mass at the expense of adipose tissue (Behnke, Feen \& Welham, 1942; Brožek, Kihlberg, Taylor \& Keys, 1963; Pařizková, 1959, $1960,1963)$. The increased accumulation of fat during rest after intensive training is not due to impairment of the regulation of food intake, and this had led us to conclude that accumulation of fat in this situation is probably the result of adaptation of metabolic processes to the previous muscular work (Pařizková \& Poupa, I963). By means of intense muscular exercise such as maximal performance on a treadmill it is possible to produce an alternation in the concentration of non-esterified fatty acids (NEFA) in the blood (Pařizková, Staňková, Șprynarová \& Vamberová, 1963). These changes suggest an increased capacity for NEFA mobilization during the period of intense muscular activity. With regard to the underlying mechanism it is known that during muscular work the concentration of catecholamines in the blood rises and that they are excreted in the urine; it is also known that catecholamines cause lipid mobilization. The release of NEFA from adipose tissue in vitro. (Gordon \& Cherkes, 1958; Reichl, 1959) and the effect of catecholamines on this process (White \& Engel, 1958; Wenke, Mühlbachová \& Hynie, 1962) in various physiological conditions has been demonstrated, e.g. after fasting in normal rats (Robinson, 1960), after fasting in obese hyperglycaemic and lean mice (Marshall \& Engel, I960), in young and old rats (Benjamin, Gellhorn, Wagner \& Kundel, 1961; Altschuler, Lieberson \& Spitzer, 1962; Tenorová \& Hrůza, 1962), and after cold acclimatization (Hannon \& Larson, 1962). We have therefore explored the problem whether, in conjunction with changes in the proportion of adipose tissue and other indicators suggesting adaptation to a more intense muscular activity, reactivity of adipose tissue to adrenaline is also affected.

\section{EXPERIMENTAL}

The weight gain in two groups of male rats (eleven trained, eleven controls) of the Konárovice strain was followed by weighing them on alternate days from the and to the 2oth day of life and subsequently once a week up to the $360 t$ day of life.

In one group training on a treadmill began on the $\mathrm{r} 60$ th day of life. The amount of training was gradually increased from 3 to $5 \mathrm{~min}$ at a rate of $8 \mathrm{~m} / \mathrm{min}$ up to $50 \mathrm{~min}$ at a 
rate of $18 \mathrm{~m} / \mathrm{min}$ in $\mathrm{I}$ day. The second (control) group lived in cages without training.

Oxygen consumption was measured in a simple laboratory calorimeter described by Luštinec (1956), which was a modification of the Regnault-Reiset calorimeter. Oxygen consumption was estimated during $20 \mathrm{~min}$ at rest and during $20 \mathrm{~min}$ after $20 \mathrm{~min}$ exercise in a treadmill, measuring per 2 min the mean consumption/roo $\mathrm{g}$ body-weight. For several days just before this measurement the rats from the untrained control group were accustomed to the treadmill during three to five rounds lasting several minutes, in order to avoid the stress inherent in an unknown situation. The duration of physical stress was selected in such a way as to enable the control animals to produce a comparable performance.

The animals received throughout life the Larson stock diet ad lib. (basic mixture $(\%)$ : wheat groats 60 , casein 15 , dried milk I I, lucerne 4 , germinating wheat 4 , soya groats 2, Convit (a mixture containing $45 \%$ germinating maize, $25 \%$ dried malt, $20 \%$ dried carrot, $10 \%$ dried yeast and 200000 i.u. vitamin $\mathrm{D} / \mathrm{g}$ ) $\mathrm{I}, \mathrm{CaCO}_{3} \mathrm{r} \cdot 6$, plastin $0.8 \mathrm{I}$, dried yeast 0.6 ; for $2 \mathrm{~kg}$ of this mixture $\mathrm{I} 1$. water, $100 \mathrm{~g}$ margarine, $\mathrm{r} 5 \mathrm{~g}$ codliver oil and $7 \mathrm{~g}$ salt were added). Between the 250 th and 270 th days of life calorie intake and the intake of different diets were investigated by the method of selfselection in individual cages: the first diet offered was the basic Larsen mixture, diluted $\mathrm{I}: 2$ with starch, the second diet was a similar mixture with casein and the third with fat (margarine).

The animals were killed by decapitation and specimens were withdrawn immediately. Some 40-60 sec after the animal had been killed, a sample of epididymal fat was put into the medium (see below) and samples of muscle were taken for determination of weight and lipid content. 'The muscle was disintegrated with sand and extracted for $2 \mathrm{~h}$ with a twentyfold volume of chloroform-methanol (2:1). After centrifugation, distilled water was added in the proportion, mixture: water, $5: 1$; after $24 \mathrm{~h}$ the methanol-water phase was withdrawn, evaporated to dryness and the residue weighed, as a measure of lipid content.

For determination of the lipid content of the body, the carcasses were put in I-2 l. of $30 \% \mathrm{KOH}$ in $50 \%$ ethanol. After complete solution, $10 \mathrm{ml}$ specimens were neutralized with $50 \% \mathrm{H}_{2} \mathrm{SO}_{4}$. This mixture was then twice extracted with $10 \mathrm{ml}$ chloroform. 'The combined chloroform extracts were shaken with $5 \mathrm{ml}$ distilled water and left to stand for $24 \mathrm{~h}$. After centrifuging, the wate: phase was removed and the chloroform evaporated at $60^{\circ}$. The residue was weighed, and from it body fat content was calculated.

Release of NEFA into the medium from adipose tissue (epididymal tissue) was investigated in vitro in Krebs-Ringer phosphate buffer with $3 \%$ albumin added. Two and four $\mu \mathrm{g}$ of adrenaline were added per $100 \mathrm{mg}$ adipose tissue. NEFA were estimated during incubation by Dole's (1956) method.

Estimations in vivo were made on two groups of eleven animals, estimations in vitro on groups of seven animals. 


\section{RESULTS}

Fig. I shows the mean weight-gain curves of trained and control animals. There was no marked difference in shape between the two curves, showing that training on the treadmill, begun on the I6oth day of the life, did not cause any change in rate of weight gain. Nor was there any significant difference between the weights of the adrenal in these two groups, the trained animals 'being $33.0 \mathrm{mg}(\mathrm{SD} \pm 8.0)$ and the controls' $28 \cdot 0 \mathrm{mg}\left(\mathrm{SD} \pm 9^{\circ} \circ\right.$ ).

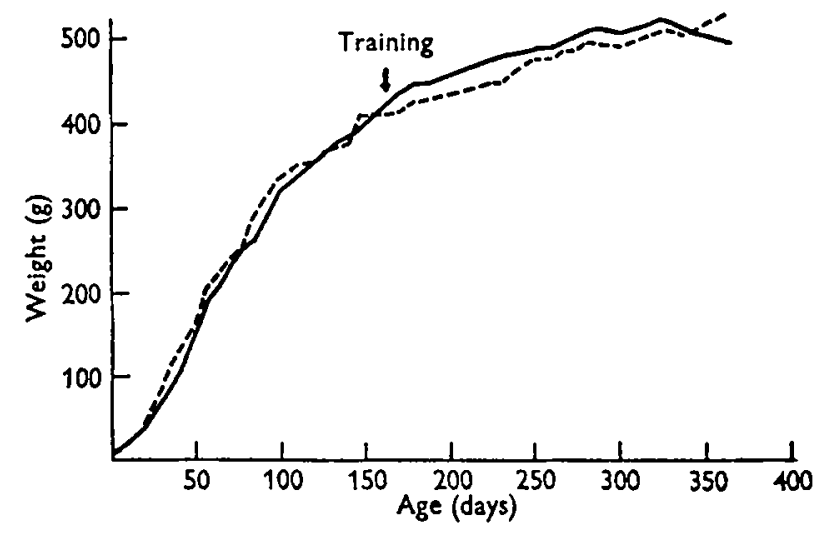

Fig. 1. Weight curves of trained $(-)$ and control, untrained (--- ) rats during 360 days of life.

The trained and control groups differed in several functional and morphological characteristics. The oxygen consumption at rest in untrained rats was $4.3 \mathrm{ml} / \mathrm{ro0} \mathrm{g}$ body-weight $2 \mathrm{~min}$ (SD $= \pm 0.94 \mathrm{ml}$ ). After stress on the treadmill it was raised to $5.3 \mathrm{ml} / \mathrm{roO} \mathrm{g}$ body-weight $2 \mathrm{~min}$ ( $\mathrm{SD}= \pm 0.94 \mathrm{ml}$ ), the increase being statistically significant $(0.02>P>0.01)$. In trained rats the oxygen consumption at rest was $4.4 \mathrm{ml} / \mathrm{IOO} \mathrm{g}$ body-weight $2 \mathrm{~min}$ ( $\mathrm{SD}= \pm 0.74 \mathrm{ml}$ ) and after the same stress remained at $4.5 \mathrm{ml} / 100 \mathrm{~g}$ body-weight $2 \mathrm{~min}(\mathrm{SD}= \pm 0.73 \mathrm{ml}$ ). A run of $20 \mathrm{~min}$ on a treadmill was a relatively small stress for animals that were adapted for it, but provided a considerable strain for untrained rats.

There was no significant difference in the total daily calorie intake per $100 \mathrm{~g}$ bodyweight (trained rats $22 \cdot 8 \mathrm{kcal}, \mathrm{SD} \pm 5^{\cdot 6}$; control rats $24^{\cdot} \times \mathrm{kcal}, \mathrm{SD} \pm 4 \cdot 7$ ). There was, however, a significant difference $(0.01>P>0.002)$ in the amount of different diets eaten between the 250 th and 270 th days of life (Table $I$ ). The trained rats selected spontaneously equal amounts of diet with a high starch and high fat content. The controls selected on average twice as much of the diet with the high fat content as of that with the high starch content. Both groups ate the same amount of the diet with the high casein content.

Although the mean weights of trained and control rats did not differ significantly, the body composition differed markedly (Fig. 2). The percentage of fat in trained rats was significantly lower, but the weights of lean body mass did not differ significantly. 
In Fig. 2, for comparison, corresponding values for young male rats are given. Another morphological difference was the difference in weight of the tibial $(P=$ 0.02 ) and gastrocnemius muscles $(0.02>P>0.01)$ (Table 2 ), which are subjected to

Table I. Amounts of different diets selected in $24 h$ by eleven trained rats and eleven control rats between the 25 oth and 270 th days of life and their contribution to total calorie intake

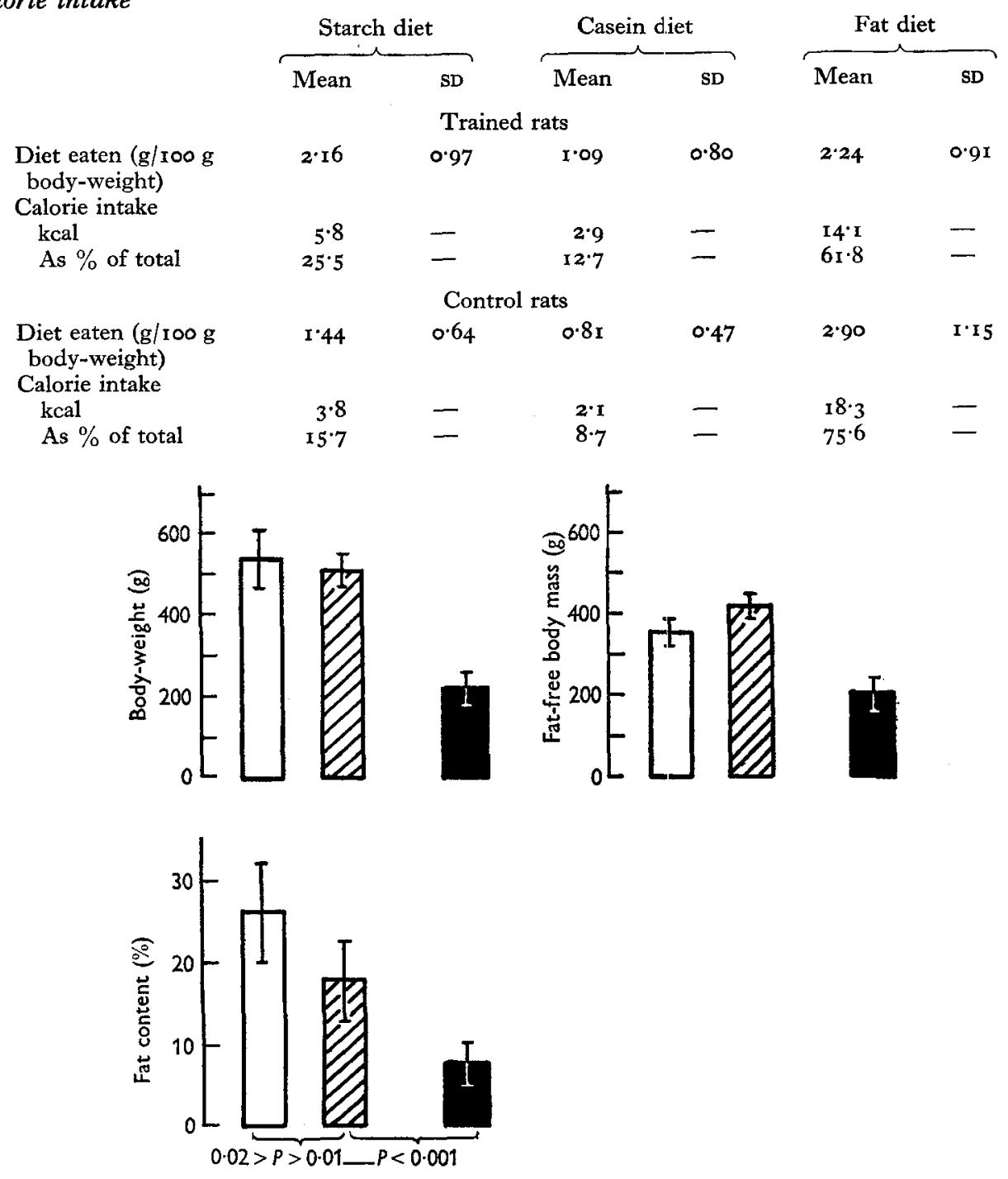

Fig, 2. Mean values with their standard errors for weight, fat-free body weight and fat content of the control rats (open columns), the trained rats (hatched columns) and, for comparison, a group of 2 to 3 -month-old rats (black columns).

the greatest strain during running. The weight of the soleus muscle, which is a predominantly postural muscle, did not differ significantly. The percentage of fat in the tibial and soleus muscles did not differ in the two groups of trained and control rats; 
in both groups the percentage of fat in the tibial muscle was lower than in the soleus muscle (Table 2).

The adipose tissue in the two groups differed not only in amount but also in its response to adrenaline in vitro. In a group of thirteen animals we investigated a suitable dose of adrenaline to evoke an adequate reaction in animals of given age and weight. There was no release of NEFA into the medium in the absence of adrenaline in trained and untrained rats and a very small and inconstant one after $\mathrm{I} \mu \mathrm{g}$ of adrenaline; for that reason doses of 2 and $4 \mu \mathrm{g}$ were used. Adipose tissue from trained rats always liberated (into the medium) a larger amount of adrenaline than did that of controls (Fig. 3). With the lower doses of adrenaline, this difference was marked, particularly after a medium or long period of action (100 $\mathrm{min})(P<0.00 \mathrm{I})$; during a short period of action (e.g. $60 \mathrm{~min}$ ) or protracted action $(210 \mathrm{~min})$ the difference was not significant. When the dose of adrenaline was doubled $(4 \mu \mathrm{g} / \mathrm{r} 00 \mathrm{mg}$ adipose

Table 2. Weights and fat contents of the tibial, gastrocnemius and soleus muscles of seven trained and seven control rats

\begin{tabular}{|c|c|c|c|c|}
\hline \multirow[b]{2}{*}{ Muscle } & \multicolumn{2}{|c|}{ Trained rats } & \multicolumn{2}{|c|}{ Control rats } \\
\hline & Mean & SD & Mean & SD \\
\hline \multicolumn{5}{|c|}{ Weight (mg) } \\
\hline $\begin{array}{l}\text { Tibialis } \\
\text { Gastrocnemius } \\
\text { Soleus }\end{array}$ & $\begin{array}{r}752 \cdot 2 \\
2477 \cdot 2 \\
148 \cdot 8\end{array}$ & $\begin{array}{r}71 \cdot 2 \\
151 \cdot 3 \\
17 \cdot 1\end{array}$ & $\begin{array}{r}677^{\circ} 0 \\
2265 \cdot 2 \\
1477^{\circ}\end{array}$ & $\begin{array}{r}33 \cdot 2 \\
128 \cdot 7 \\
26 \cdot 7\end{array}$ \\
\hline \multicolumn{5}{|c|}{ Fat content $(\%)$} \\
\hline $\begin{array}{l}\text { Tibialis } \\
\text { Soleus }\end{array}$ & $\begin{array}{l}2.49 \\
3.66\end{array}$ & $\begin{array}{l}0.39 \\
0.60\end{array}$ & $\begin{array}{l}2.65 \\
3 \cdot 70\end{array}$ & $\begin{array}{l}0.55 \\
0.80\end{array}$ \\
\hline
\end{tabular}
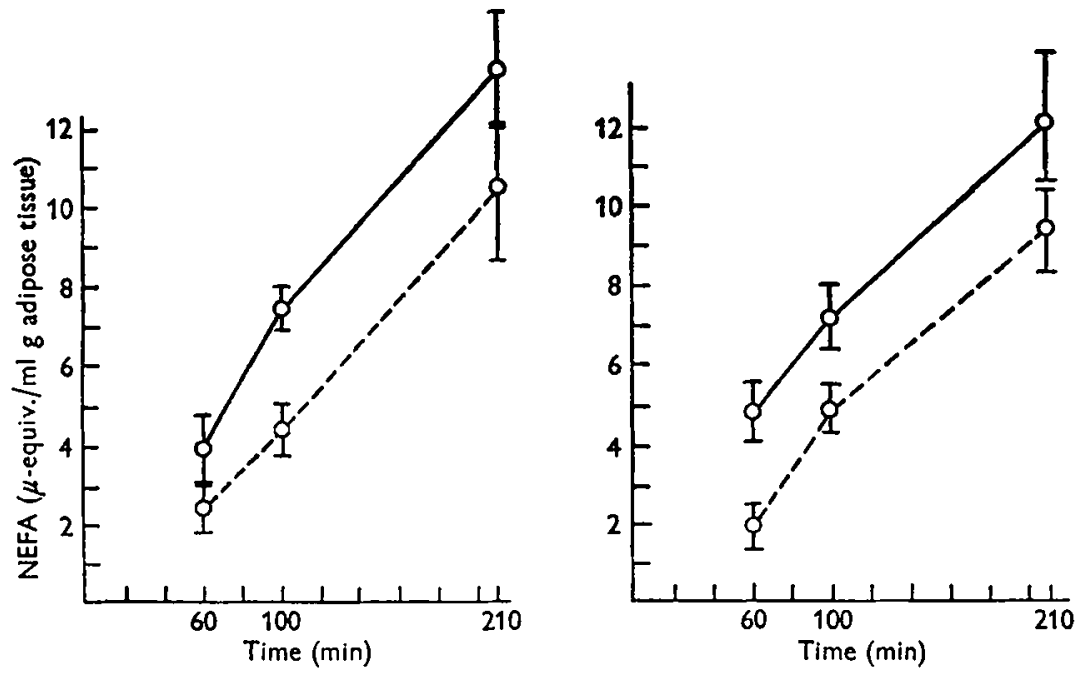

Fig. 3. Mean values with their standard errors for release in vitro of NEFA by adipose tissue of trained $(0-\infty-0)$ and untrained $(0--0--0)$ rats, after 60,100 and $210 \mathrm{~min}$, when 2 (left) or 4 (right) $\mu \mathrm{g}$ adrenaline/ $100 \mathrm{mg}$ adipose tissue had been added to the medium. 
tissue), after $60 \mathrm{~min}$ the release of NEFA from adipose tissue of trained animals increased somewhat, but it decreased in the controls, the difference being significant $(0.02>P>0.01)$. After $100 \mathrm{~min}$ the release of NEFA. from adipose tissue was again significantly higher in trained animals $(0.05>P>0.02)$; after protracted action there was no significant difference.

\section{DISCUSSION}

To avoid exposing the animals to stress during training on the treadmill it is important to increase the rate and work load very carefully. A relatively reliable indicator of whether the animals are not excessively strained is the shape of the body-weight curve, as compared with that of the control group, and the weight of the adrenal glands. The results of investigations of these indicators in our groups of animals revealed that excessive stress did not take place. On the other hand, it is essential that the stimulus, i.e. in our experiments the imposed muscular activity, rnust be biologically sufficiently intense. Further functional and morphological indicators investigated suggest that the training on the treadmill caused some changes typical for an organism adapted to a higher intensity of exercise, e.g. oxygen consumption, the weight of the muscles exposed to strain, or body composition. Mayer, Marshall, Vitale, Christensen, Mashayekhi \& Stare (1954) demonstrated that running on a treadmill for not more than $\mathrm{I} h$ daily does not increase the calorie consumption of rats. We found the same with our experimental groups. On the influence of exercise on the self-selection of food, Andik, Bank, Móring \& Szegvári (1954) investigated selection in $300 \mathrm{~g}$ male rats during 40 days of prolonged daily exercise, involving; some $8-9 \mathrm{~h}$ at $750 \mathrm{~m} / \mathrm{h}$. 'The intake of food rich in starch decreased, while consumption of casein and fat-rich food increased. This selection resulted in a marked increase of calorie intake without an increase in the bulk of food consumed. In our experimental group the weight of ingested diet was also equal in the two groups; the trained animals ingested, however, a greater proportion of the high-starch diet, obviously owing to the fact that they had gradually become adapted to the stress and so did not need to increase their total calorie intake.

The differences in the proportion of fat in the animal carcasses correlate with the different reactivity in vitro of the adipose tissue to adrenaline. There was a greater ability of trained animals to release NEFA into the medium in response to the same amount of adrenaline, in particular with larger doses and after short periods of incubation. The animal adapted to a greater intensity of muscular work is able to respond to this humoral stimulus more rapidly and with more intense mobilization of NEFA from adipose tissue than the untrained animal; the trained rat is probably also capable of utilizing NEFA to a greater extent as a source of energy during work. This was proved in migratory birds adapted in the course of phylogeny to intense muscular work (Drummond \& Black, I960). The results of our experiments could imply that increased ability to mobilize fat may develop also during ontogeny after a certain time of imposed muscular activity when the organism becornes adapted. A similar result in cold-acclimatized rats was found by Hannon \& Larson (1962). The effect of exertion on the treadmill markedly influenced the metabolism of adipose tissue, though the 
DNA and RNA, collagen and non-collagen $\mathrm{N}$ in those muscles in which only a small difference in weight was found did not differ, as demonstrated in the same animals by D. Bartošová (to be published). It appears thus that adaptation to more intense muscular activity manifests itself sooner and more markedly in adipose tissue as regards its total amount and reactivity. In addition, a difference in fatty acid composition in adipose tissue was found, the content of palmitoleic acid being significantly lower in trained animals (Kohout, Braun \& Pařizková, to be published).

\section{SUMMARY}

x. Two groups of male rats were studied during 360 days; one began training on a treadmill on the $\mathrm{r} 60$ th day of life. The duration and rate of exercise were gradually increased to $18 \mathrm{~m} / \mathrm{min}$ for a period of $50 \mathrm{~min} /$ day.

2. The weight curves and the weights of the adrenals were the same in both groups. The difference between trained and untrained manifested itself in a different body composition, the trained animals containing a lower proportion of fat. The weights of the tibial and gastrocnemius muscles of trained animals were significantly greater; the percentage of muscle fat did not differ in the two groups.

3. After $20 \mathrm{~min}$ run on the treadmill untrained rats showed an increased oxygen consumption but there was no change in the trained group. The daily calorie intake/ $100 \mathrm{~g}$ body-weight did not differ between the groups; trained rats, however, selected spontaneously equal amounts of the high-starch and high-fat diets, and the controls selected twice as much of the high-fat diet. The amount of high-protein diet ingested was the same in both groups.

4. The adipose tissue of trained animals, apart from forming a smaller proportion of the body, released more non-esterified fatty acids into Krebs-Ringer phosphate than did adipose tissue from untrained animals after an equal amount of adrenaline had been added to the medium. After $2 \mu \mathrm{g}$ adrenaline/100 $\mathrm{mg}$ adipose tissue had been added, the difference was significant after $100 \mathrm{~min}$; when $4 \mu \mathrm{g}$ adrenaline were added an increase of NEFA release was observed in trained animals but in untrained animals there was a decrease after $60 \mathrm{~min}$.

\section{REFERENCES}

Altschuler, H., Lieberson, M. \& Spitzer, J. J. (1962). Experientia, 18, 9r.

Andik, I., Bank, J., Móring, I. \& Szegvári, Gy. (1954). Acta physiol. hung. 5, 457.

Behnke, A. R. Jr., Feen, B. G. \& Welham, W. C. (1942). F. Amer. med. Ass. 118, 495.

Benjamin, W., Gellhorn, A., Wagner, M. \& Kundel, H. (196r). Amer. F. Physiol. 20r, 540.

Brožek, J., Kihlberg, J. K., 'Taylor, H. L. \& Keys, A. (1963). Ann. N. Y. Acad. Sci. 110, 492.

Dole, V. P. (1956). F. clin. Invest. 35, 150.

Drummond, G. I. \& Black, E. C. (1960). Annu. Rev. Physiol. 22, I69.

Gordon, R. S. Jr. \& Cherkes, A. (1958). Proc. Soc. exp. Biol., N.Y., 97, 150.

Hannon, J. P. \& Larson, A. M. (1962). Amer. Y. Physiol. 203, 1055.

Luštinec, K. (1956). Čs. Fysiol. 5, 250.

Marshall, N. B. \& Engel, F. L. (1960). J. Lipid Res. 1, 339.

Mayer, J., Marshall, N. B., Vitale, J. J., Christensen, J. H., Mashayekhi, M. B. \& Stare, F. J. (1954). Amer. F. Physiol. 177, 544.

Pałízková, J. (r959). Cs. Fysiol. 8, 426.

Pařizková, J. (1960). Čs. Fysiol. 9, 253.

Pay̌izková, J. (1963). Ann. N.Y. Acad. Sci. 110, 661. 
Pał́zková, J. \& Poupa, O. (1963). Brit. F. Nutr. 17, 341.

Pał́zková, J., Stał̌ková, L., Śprynarová, S. \& Vamberová, M. (rq(ij). Cs. Fysiol. r2, 332.

Reichl, D. (1959). Physiol. bohemoslov. 8, 514.

Robinson, D. S. (1960). 7. Lipid Res. 1, 332.

Tenorová, M. \& Hrüza, Z. (1962). Cs. Fysiol. rr, 169.

Wenke, M., Mühlbachova, E. \& Hynie, S. (1962). Proceedings of the 5th National Congress of the Czechoslovak Physiological Society, p. 82. Prague: Czechoslovak Academy of Sciences.

White, J. E. \& Engel, F. L. (1958). Proc. Soc. exp. Biol., N.Y., 9!) 375. 